\title{
Toward Building a National Innovation System in UAE
}

\author{
Yousif Al-Abd, Toufic Mezher* \\ Masdar Institute of Science and Technology, Abu Dhabi, UAE
}

\begin{abstract}
United Arab Emirates (UAE) is one of the developing countries that depend on hydrocarbon products in supporting its economy, where oil activities counted for $49.38 \%$ of its total GDP (Gross Domestic Product) in 2009. Therefore, Abu Dhabi (AD), the capital of the UAE, has a vision where in 2030 the country will decrease its dependency on fossil fuel to $36 \%$ in order to stabilize the economy. Through AD strategy, a number of new industries have been planned to enter in order to diversify the economy. Some of the investments are believed to be a very high tech and innovation driven industries, such as the aerospace manufacturing industry. The aim of this paper is to analyze different countries' national systems of innovation, which have been selected based on literature where innovation is measured through number of KPIs (Key Performance Indices; R\&D expenditures, number of research institutions, patents, number of engineers, new companies established, exports, etc). KPIs will be mapped from an innovation system perspective including the ones from UAE. Then a gap analysis will be conducted to determine where the country lags in terms of establishing a healthy national innovation system. A number of strategies will be suggested to enhance the UAE national innovation system.
\end{abstract}

Keywords: Innovation, Networks, Technology, Knowledge, R\&D, Institutions, Universities, Engineering

\section{Introduction}

United Arab Emirates (UAE) is a hydrocarbon products dependent economy and revenue from hydrocarbon sale production accounts for 55 percent of the country's GDP. Abu Dhabi, the capital of the UAE presents the largest share of the country's oil and hydrocarbon market [4]. Since, hydrocarbon based economies, are considered to be unstable economies due to their dependency on the fluctuating global oil prices, therefore, Abu Dhabi government decided to diversify its economy. This was highlighted by his highness Sheikh Khalifa bin Zayed Al Nahyan the ruler of Abu Dhabi and the UAE [5]. Aircraft manufacturing industry, semi-conductors industry, and various others were identified as important areas of development in Abu Dhabi's move toward the diversification. Successful diversification requires intensive planning. It is essential to study the impact of the selected strategies on the overall system to mitigate risks and financial losses. In addition, evaluating industries beforehand will ease their success,

${ }^{*}$ Corresponding author. Tel.: +97128109160

E-mail: tmezher@masdar.ac.ae

(c) 2014 International Association for Sharing Knowledge and Sustainability

DOI: $10.5383 /$ ijtee. 07.02 .008 commercializing process, and minimize investors' skepticisms.

Systems innovation (SI) approach has different advantages when compared to the linear economical model (Neoclassical approach). The linear, push and pull approach between supply and demand deals with the economy from a static perspective or from cycle viewpoint. Dealing with an economy based on neoclassical supports forecasting as well as decisions that can be made based on an old experience which on the other hand the SI approach considers as history [6]. SI approach deals with economy in more dynamic manner in which decisions cannot be made based on history. Furthermore, the SI approach deals with the SI actors in an integrated fashion so that they should not be isolated. Prosperity requires that interactions with different firms, actors, and institutions should exist [7]. Therefore, the paper will aim at studying five different countries national innovation systems (NIS) toward identifying possible gaps in the UAE NIS, and propose possible policy aimed recommendations which can support the creation, diffusion, and utilization of knowledge in the UAE. 


\section{Systems of Innovation as a Theoretical Framework}

\subsection{Introduction}

David J. Spielman traced the innovation studies to Adam Smith by being the first to notice the innovation effect on new production techniques, yet in the same work Spielman emphasized that the scholar who was behind putting the main pillar in the recent innovation systems studies was Joseph Schumpeter [8]. Therefore, innovation work goes back to 1911 through the "Theory of economic development" that has been written by the German scholar Joseph Schumpeter in his mother language [9], at which Schumpeter distinguishes between invention, innovation, and diffusion [8], Therefore, and for his research and work he has been referred to as the "prophet of innovation" [9].

Based on what has been mentioned in the above paragraph, innovation has been differentiated from invention. Invention is the first establishment of an idea to create a new product or process, on the other hand innovation has been defined as the action of commercializing the idea through carrying it to practice [10]. In addition, the OECD defines innovation system as:

"An innovation system is a network in which actors interact and exchange both codified and tacit knowledge to undertake innovative activities. Knowledge is the key commodity in an innovation system and a network provides channels through which knowledge flows. Such a system is based on complex relationships that involve learning, a fundamental process in innovation. Many actors (such as firms, suppliers, customers, and education and financial institutions) interact in a specific environment that is shaped by history, culture and social relations. The resulting dynamics characterize a specific innovation system." [11].

The concept that inventions had no any necessary effect on economy can also be seen in Mason's definition of invention; using any new method, or implement in performing any action [12]. 1980's was the start of innovation systems emergence as a development of the Schumpeterian (Neo- Schumpeterian). It was basically drawn from the evolutionary and systems theory, which considers the high non-linearity characterized endogens process of technology and institutional change.

Chris Freeman was the first to apply the national innovation systems concept, in order to investigate as well as describe the performance of Japan. In his work (Freeman) he highlighted important elements in Japan's national innovation system which supports its innovation creation, development, and diffusion supporting its economical growth [13].

Before going deeper into the SI literature defining systems would be at this point a right step to be done. Dealing with a system of innovation approach as a frame work, the one can be confused as well as curious to understand the "System" definition as best fits the innovation and the economy perspective.
Lundvall gave a definition for systems as "anything that is not chaos". Despite of the broad definition of systems, Lundvall went into more specific manner in defining systems, in more specific, systems has been defined as a number of elements (components) which has relations in between. Follows, systems in innovation, the elements interact for the purpose of production, diffusion and use of new knowledge that have economic advantages. ([14]: 2)

Systems of innovation have been defined as "all important economic, social, political, organizational, and other factors that influence the development, diffusion, and use of innovations." ([14]:14), where Landvall defined it as a system which includes all components that create the economical structure or affects it as well the institutional set up, working and interacting towards affecting learning, searching, and exploring the production system, the marketing system...etc., in addition to sub systems in which learning takes process. ([14], 13)

According to Carlsson and Stankiewics (1991), "Actors", "Interactions", and "Institutions are considered as main components of any innovation system [15]. In a work done by Shu Gao, and Harro van Lente (2008), they underlined basic differences between the different SI perspectives; national innovation systems (NIS), regional innovation systems (RIS), and sectorial innovation systems (SIS). Based on their work the different perspectives differs on their level of analysis e.g. the NIS analyze the innovation at the country level where SIS puts its focus more on the industry level [16]. Adding to this, a study that has been done by Richard R. Nelson, where he compares between SI approach (evolutionary and institutional approach) vs. the market failure approach (Neo-classical economics) for technology policy, and the study shows to a great extent the value of the SI in analyzing economical actions when compare to the market failure approach [6].

A first difference based on his work was that; under the neo-classical, changes are well anticipated since it considers economy as in equilibrium or undergoes expected changes. On the other hand, economy faces continuous changes that make it unpredictable by its actors. This change has been highlighted to affect the rational behavior of the economical individuals. The second difference was; the market failure approach sets a theoretical optimal for economic performance where in the SI approach the economic performance is being measured by the rate of its growth. Therefore, his work reveals a basic problem of misallocation of resources which can exist when using the market failure approach as well as innovation will be restricted since the market failure believes that there is always one default market structure for investors, entrepreneurs,...etc. should stick to.

Despite of the great mentioned characteristics of the SI, some of the literature criticized its static perspective [17]. Innovation functions obliterated the static criticisms where they study the system dynamics and that can be done by measuring how well is each function 
has been served in the system. Some of the proposed functions were; entrepreneurial Activities; knowledge Development; knowledge diffusion through networks; guidance of the search; market formation; resources mobilization; creation of legitimacy [18].

\subsection{National Innovation System History and Definition}

NIS focuses mainly on interactions and linkages (described in the following sections) between the system actors (primarily private enterprises, universities and public research institutes and the people within them), and it relies on the fact that a county's innovation performance depends largely on the level of interactions between the system actors in the creation and use of knowledge and technologies [19].

The NIS has been with a considerable focus in economical analysis and policy issuing processes [20]. The first time it has been used can be referred to Freeman in his book about Japan as what Lundvall highlighted in his book "National systems of innovation: Towards a theory of innovation and interactive learning" [21]. Adding, the literature highlighted a number of different definitions which were provided by Niosi as shown in Table 1 [21].

\section{Table 1. NIS different literature highlighted definitions}

"The network of institutions in the public- and privatesectors whose activities and interactions initiate, import, modify and diffuse new technologies" [22]

"The elements and relationships which interact in the production, diffusion and use of new, and economically useful knowledge... and are either located within or rooted inside the borders of a nation state" [23]

"The set of institutions whose interactions determine the innovative performance of national firms" [24]

"The national system of innovation is constituted by the institutions and economic structures affecting the rate and direction of technological change in the society" [25].

"The national institutions, their incentive structures and their competencies, that determine the rate and direction of technological learning (or the volume and composition of change generating activities) in a country" [26].

"That set of distinct institutions which jointly and individually contribute to the development and diffusion of new technologies and which provides the framework within which governments form and implement policies to influence the innovation process. As such it is a system of interconnected institutions to create, store and transfer the knowledge, skills and artifacts which define new technologies" [27].

"A national system of innovation is the system of interacting private and public firms (either large or small), universities, and government agencies aiming at the production of science and technology within national borders. Interaction among these units may be technical, commercial, legal, social, and financial, in as much as the goal of the interaction is the development, protection, financing or regulation of new science and technology" [28].
From Table 1, a common feature can be noticed, all mentioned definitions focuses on the networks and interactions between actors.

\subsection{NIS Building Blocks}

Actors, elements, linkages and flows of the NIS have been mentioned in the above previous paragraphs. In the following paragraph, the building blocks of the NIS will be described in some more detailed level.

NIS building blocks are mainly institutions and linkages [21]. Based on Johnson, institutions are "set of habits, routines, rules, norms and laws, which regulate the relations between people, and shape social interaction", he also highlighted that institutions can also refer to organizations which are normally referred to as formal institutions.

Institutions play a great role in the system, which can be innovation stimulates or damper, where institutions provide incentives, resources, and information, increase clarity, and reduce conflicts [21]. It can be seen that damping innovation process can occur through institutions that are faulty which for example missallocated resources.

As a second unit of the NIS building blocks which might occur or might not, is linkages and flows. Linkages and flows comprises financial, human, and knowledge flows and linkages which can occur between the system formal institutes, such as firms, R\&D labs, government...etc. [21].

In Jorge Niosi, Paolo Sa viotti, Bertrand Bellon, and Michael Crow work, they highlighted in somehow clearer approach of the NIS building blocks being:

1- Firms and institutions ${ }^{1}$ which can be:

a. Private innovating companies (they stand for the highest share of technological innovation).

b. Universities, government labs, or state corporations.

c. Governmental coordination, or financial agencies

2- Links and flows, which can be:

a. Financial

b. Legal and policy such as; intellectual property rules, technical standards, and technology and procurement policy

c. Technological, scientific, and informational flows

\section{Countries National Innovation System Brief}

\subsection{US National Innovation System}

The US in post-1953 era was characterized by high R\&D investments, representing the highest in comparison to the remaining OECD countries combined [29]. The US

\footnotetext{
${ }^{1}$ Here institutions is meant to be formal institutions such as universities...etc
} 
innovation system has been different from all because of two reasons; its antitrust status, and its military research importance, and its system revealed great results in the pre-1970s era which US failed in sustaining, yet the US share of Nobel prizes indicates a strong system of research performance and innovation. [29].

\subsubsection{The US system before 1945}

The American economy during this era faced a huge boom due to large scale innovative productions in manufacturing industries. (It was noted that this was due to production of light machines and mechanical devices. Innovations did not rely on hardcore scientific research but on the import of foreign sources of knowledge and skilled tinkerers, which supported the economy through mass-productions, which was due to unique systems of organizational work and hierarchy in companies, such as 'Fordist/Taylorist' system which led to low investment on workers' skills, high output and better technological development [30]. The development of these industries led to the spurt of small industrial laboratories on material analysis and quality control which employed scientist and research personnel. This was the beginning of the large scale dedicated research facilities [29]. The US antitrust policy influenced many structural changes in many large US manufacturing firms. The Sherman Antitrust Act in the late nineteenth century kept strict control of prices and output. Due to this policy there was a large surge in mergers especially horizontal mergers during the period of 1895-1904 so that firms could control prices and markets [31]. Industrial research supported corporate diversification and the use of patents to attain or retain market power. For the much of the pre1940 period, most of innovations where built based on external inventions [29].

The major industrial research activities during the early twentieth century were dominated by the chemicals and related industries. These industries dominated the employment rates with $40 \%$ of research scientists being employed in these sectors [32]. Employment of scientists and engineers in industrial research within manufacturing grew from 3,000 in 1921 to nearly 46,000 by 1946 [33]. In addition to chemical and electrical machineries, the US started performing R\&D in transportation equipments including aircrafts reaching the number one place by 1946 , and that was due to the Federal support of research, Federal procurement, and the rapid growth of automobiles industry [29].

After 1940, heavy government funding of wartime industry contributed to the research employment within electrical machinery and instruments. During WWI also, the government had to support research for munitions industry because the necessary technical and scientific expertise was not available in the private sector. To support scientific research, NACA (National Advisory Committee on Aeronautics) was founded in 1915 to "investigate the scientific problems involved in flight and to give advice to the military air services and other aviation services of the government", which was absorbed by NASA (National Aeronautics and Space Administration) in 1958 [34]. Federal expenditures during 1930 s for R\&D contributed only $12-20 \%$ of the total US R\&D expenditures. Industries accounted twothirds of the total. The rest came from universities, state governments, private foundations and research institutes [29].

Linkages started building up between industrial and academic research fuelled by the decentralized structure and funding of the US higher education system. Moreover the state government funding helped the state to control and manipulate the curriculum according to the market requirements resulting in great commercial opportunities. New programs were introduced and hence new specialists created as soon as the needs of the local economy would get clearer. This was not true in Europe at that time. Thus the US higher educational system outstripped that of its counterparts in Europe [29].

\subsubsection{The US post war system}

After the war the US SI has changed a lot, federal government got involved in research and total R\&D expenditure rose dramatically in 1945 in comparison to 1940, which yielded several important legacies. Adding, and during the same period, Office of Scientific Research and Development (OSRD) was created which funded the private $\mathrm{R} \& \mathrm{D}$, at which MIT (largest receptor) received \$116 million contract, worth noting that OSRD successful contracts stimulated the private $R \& D$ importance to government [29]. The post war system can be basically differentiated by the national $R \& D$ investments magnitude, and the size of federal funding, where as late as 1969 the US R\&D expenditures (\$25.6 billion) exceeded West Germany, France, UK and Japan combined $\mathrm{R} \& \mathrm{D}$ expenditures ( $\$ 11.3$ billion) [35].

In the post war era a bias in federal research funding can be seen in favor to military, and such intensive military research and funding strengthened the commercial innovative capabilities of many US firms, where defense procurement lowered the market boundaries. Due to this, small firms like General Radio, Texas Instruments etc. could concentrate their efforts in meeting the demands of their single largest customer, the military [29]. Another basic difference between the post was and prewar eras is the expansion of research in US institutions of higher learning, and this is basically due to the increased role of the federal in both funding research and demanding more universities research, also the federal increased the pool of But it helped in increasing the pool of scientific personnel as well as acquisition of physical equipment and facilities essential to the performance of high-quality research, by that it also strengthened the bondage between research and teaching [29].

Private industries played a huge role in the US R\&D especially during the cold war in 1985, also small firms proved their importance. Innovative individuals created their own firms and where supported by venture capital which supported the overall US R\&D [29]. Adding, postwar US antitrust policy also helped the startup firms, 
and led to the liberalizing of the patent licensing terms. The government also controlled the commercial production of the large technology firms to provide a breathing space for start-ups. During the 1950s and 1960s the US military also provided a springboard to the startup firms in microelectronics and computers. The US armed services started awarding major procurement contracts to the startup firms with little track record to boost confidence unlike the European policies. This led to competition and hence more $\mathrm{R} \& \mathrm{D}$ in the private sector [36].

During the postwar period large research firms like GE, Du Pont were forced to move their Central Research facilities to applied research and then to product divisions. But as the central research laboratories expanded and manufacturing firms diversified into new product lines, the ties between departments weakened. Due to lack of communications, the work could not be commercialized. A slowdown in the domestic economy in the 1970s led these huge firms to budgetary and cutbacks [29].

\subsubsection{Policy challenges and structural changes in the 1980s}

Globalization undercut America's postwar superiority, where technology mobility supported the transfer of technologies from US to other countries. Therefore, industries to realize that more fields of research in universities could result in generating more findings that could be of commercial significance. This led to a growing role of US universities in basic research, in addition to the need of decreasing R\&D cost. Also, firms started to develop external sources of research and development expertise and expanded both international and domestic collaborative research, due to several reasons; rising costs/risks of product development, Increase the exposure to scientific and technological knowledge, competitive pressure from foreign firms [29]. The "magic of the market" i.e. the startup firms are now being criticized by observers for being money oriented and focusing only on the short term results and providing insufficient support to technology development in the long run. The US venture capital market and other financing institutions are also being criticized. While other critics say that these startup have led to excessive transfer of technological know-how to foreign firms especially the Japanese firms (who invested in these companies). Hence this concludes, without much evidence, US economy difficulties are a result of startup firms [24].

During the past decade, the US government during the past decade has recognized the important role of innovation in economic performance and has taken numerous steps to increase the domestic economic payoff from large public and private US investment in R\&D.

- Changing Relationship between military and civilian technologies
The mindset of the government now focused on developing new commercial technologies with the belief that these technologies would help advance in military applications, unlike in 1950s and 1960s. With the military demand for many high-technology systems decreasing, the major defense suppliers have to focus on commercial applications. Many firms like Sematech and National Center for Manufacturing Sciences (NCMS) cater both military and civilian needs. Many suggestions to Pentagon are for similar initiatives, but Pentagon may resist diversion of funds to "dual-purpose" R\&D and procurement programs.

\section{- Intellectual property and antitrust}

There are various initiatives to improve intellectual property protection and reduce antitrust restrictions on collaboration in research. One such example being strengthened protection to patent holders by the 1982 legislation. The Reagan administration tried to leniarize the antitrust policies by reducing penalties for collaboration among firms in pre-commercial research. This was done by the 1984 National Cooperative Research Act (NCRA) [37].

- Merger of technology and trade policies

The growing political salience of national science and technology policies has blurred the boundaries between U. S. technology and trade policies and has complicated policy formulation in each area. Technology-intensive industries now are at the center of bilateral trade disputes and negotiations.

The trade policy makers got closely involved with the technology policy makers in one international negotiation between US and Japan. US negotiators have also got involved in bilateral negotiations with Thailand, Taiwan and South Korea.

\subsection{France National Innovation System}

The French NIS consists basically of a number of sectors subsystems that are vertically related, which are also related to the State. Some of the major subsystems that were mentioned in the literature are systems which are related to electricity generation, telecommunications, space, arms production, and electronics in addition to more systems where the intervention of the State as well as State enterprise networks do exist. It is worth mentioning that the State almost represented in all fields where it has created an R\&D capabilities and searched for industrial partners to transfer the created knowledge since 1970s [24]. In 1676 he French Academe of science was established to foster science and it played a great role in the $18^{\text {th }}$ century by supporting industries with the created knowledge [38].

During 1740's a pivotal element was placed of the Napoleonic revolution which came to improve both social and economic sciences. This also describes the reason behind resources allocation toward military production as well as industries [24]. During 1810's 
period the College de France, the Ecole Polytechnique, and the Museum d'Histoire Naturelle were the world's leading scientific institutions [39]. Despite such success, and once the Napoleonic state started to stabilize, research-industry ties have been neglected from the private sector, and some of the locally produced science and technology started to be utilized economically outside France [37], which led to an end of France scientific era and made France lose its war against Germany in 1870[39]. In addition, the literature highlighted other reasons for Frances slow science growth being the slow economic expansion of France [40]. France slow economic expansion reasons were reasoned due to; strong leverage of the agrarian structure who owned a huge area of the State land, and therefore most of business depended on ranting lands and selling which stimulated the need of a strong financial system and financial system was Frances main focus and it neglected industries, other mentioned reasons were limited resources of coal and steel, and static internal and external demand, and market pull characterized demands which depended on foreign resources [39].

Toward the Napoleonic revolution aim, a restructuring of the education system occurred between 1806 and 1811 [41].Yet, Napoleon re-structured the education system in a similar way of the ancient conservative system which resulted by giving a higher value for experts training instead of real science researchers, and such students have been taught the result of science not the methods of science [39]. In order to overcome the conservative environment, a number of policies during 1880s were issued which supported the creation of decentralized universities system rather than the Grands Eliets, yet universities failed to sustain their selves and some researchers ended up with no funds to perform research, which was solved in 1910 by the creation of the CNRS (National Center for Scientific Research ) institution [39].

\subsubsection{Phases in building of the system}

Economic planning, industrial policies, infrastructure investments, and France huge investments in science, $\mathrm{R} \& \mathrm{D}$, and technology played a major role in France's recovery after the Second World War, in addition to its infrastructure overall reaching one of the best infrastructures, and in thirty years France succeeded in building and leading various industries due to their $R \& D$ and an intensive S\&T institutions building [39].

\subsubsection{Institution building after war}

High capacity R\&D was the selected solution in the rebuilding process of France, and policies focused on similar research targets, also France worked on the expansion of the CNRS and building further institutions that focused on various research areas.

\subsubsection{Institution Building in the First Phases of the Fifth Republic (1958-1966)}

The State had been still the source behind innovation, nevertheless, policies started to be legislated to stimulate innovation across the industry's national champions ${ }^{2}$ at which state-industry links were created. Private sector started to perform governmental R\&D in different field with the military as an exception which stayed as confidential [37].

\subsubsection{Developments in the 1970s and 1980s and the 1982 Reforms}

Mostly in the 1970-1980 period, the French innovation didn't face any dramatic changes yet in this period emphasis on R\&D, resource allocations, and entrepreneurial activities were active. In this period the private sector started to perform a great percentage of the overall R\&D performed in France, also a novel steps were taken at this period by France toward building links and bridges between companies and firms with capabilities of creating an economical value of innovative products and the public research centers, adding the state started to push public R\&D institutions to go downstream to the market and become "technological entrepreneurs". A step toward R\&D privatization can be seen in this period, where $R \& D$ laboratories status started to change from administrative public institutions to a new generic type of status with some attributes of private law which gave laboratories the power to create subsidiaries, acquire shares, and seek industrial partners collaboration on certain projects which helped in supporting the "technological entrepreneur" concept.

\subsubsection{R\&D structure}

France R\&D funds can be traced back to three major sources; $50 \%$ of the total R\&D funds are from the government, $44 \%$ are from industries, and the rest are form foreign investments, and $55 \%$ is being performed by industries. R\&D activities in France can be categorized into three main categories based on R\&D performing firms, which are government labs and universities which are owned by the state, and R\&D performed in industries and firms. Regarding the industrial $\mathrm{R} \& \mathrm{D}$, the literature tourist attractions that in 1987 around 1900 firms performed R\&D internally, yet on the other hand it can be noticed that a group of firms around 150 firms accounts for almost $75 \%$ of the industry R\&D and receives more that $90 \%$ of the total $R \& D$ funds. Within universities $R \& D$ is mainly concentrated in the specialized laboratories slightly separated from teaching. There are different agencies that played the role of knowledge and technology created circulation. Such agencies were created in order to

${ }^{2}$ large public or private firms with which the State has decided to build up in order to work in close partnership with them 
create joint ventures between different research labs and the industry [42].

\subsection{Japan National Innovation System}

In 1868 Japan leaders realized how delayed was Japan in technological fields comparing to western countries, therefore, a number of actions were made by the Japanese government in order to overcome such delay; superior technologies were imported, foreign engineers were hired, educate its citizens, and stimulates entrepreneur activities. The literature highlighted that importance of entrepreneurs where the Japanese development cannot just be attributed to governmental efforts or policies without entrepreneurial activities which can be noticed during the Meiji Restoration, through new business ideas and unfamiliar business models started by entrepreneurs [43].

\subsubsection{The Tokugawa Era and before, up to 1868}

Technology transfer took place twice: First through envoys and chine's immigrants during the 17th to 19th century period, and second was during the 16th century during the civil war when the Portuguese introduced the guns. During this era mainly the Japanese depended on the Dutch since and Dutch translated books, which was as well the only connection between japan and the western countries, yet it was restricted to a huge extent, which Meiji Era overcame [44].

In terms of the indigenous technology:

1- Irrigation systems and river improvements due to the high importance of planting (civil engineering technology is believed to be high)

2- Mechanical systems (karakuri moving mechanism) used in clocks, rice polishing and many other applications

3- The education level was high as well as literacy rate which was higher in elementary school than US and Europe, yet lower in the higher education since it started in early 19 th century.

\subsubsection{The Meiji Era: $1868-1911$}

The end of the seclusionism in 1854 in addition to a nonfeudal central government prompted the level of technology importation by both the Japanese government and the public, therefore, the government started to modernize the country through improving its infrastructure [42].

Generally, Japan through this era depended on a number of ways in importing technology; transferring written information (e.g. papers, books), hiring foreigners and sending Japanese to study abroad (people), importing machines and plants (goods), and through foreign investments (capital)([42],[45]) .

For instance, for building the national education system an American influence through hiring American specialists existed which was diluted when the nationalistic education was introduced. Another example was in building the higher education system which focused on the fields of engineering and technology, and was influence by the British [42].

In 1886, two colleges were merged, Kogakuryo engineering college (established in 1873) and another college that was established to teach science and technology and they became the engineering department of Imperial University. Graduates from the university as well as the college were owners of major manufacturing Japanese companies (Entrepreneurship activities). Adding, in the education system the interaction between the class room studies and on-site training was emphasized. In 1870's and early 1880's the government owned and built plants and factories in industries such as mining, railroad, shipbuilding, machinery, and textile, where it was expensive for citizens (private sector) to invest in such fields in addition to related knowledge scarcity. It is worth mentioning that most of governmental factories faced losses and where gradually sold to private entrepreneurs [42].

The government retained plants in military related industries, where by that time military related productions occupied a significant portion of Japans economy, where the government was keen to build its military to deal with China and countries colonizing with it. Adding the military plants were as well a center of technology development and they hired huge number of skilled engineers in addition to importing new technologies. The military helped the economy through different aspects where the highly trained engineers started to create their own manufacturers and factories, also the military procurement focused on domestic suppliers and that gave the Japanese manufacturers the ability to learn, accumulate knowledge and survive against giant technology foreign owners [42].

\subsubsection{Between the Two world wars: 1914-1945}

Richard R. Nelson in his book highlighted that economy took of place in mid 1910s in Japan, where most industries have been built, and the education system started to supply professional engineers and technical people who had the ability of handling more and more advanced technologies, he also added that access to foreign knowledge and technologies became easier through different means.

WWI played a positive role in enhancing the Japanese scientific base, where during the war the ability to import products became tough which gave a trigger for Japanese entrepreneurs to start producing local products using foreign technologies. Adding, after the WWI industrials had the ability to convince the military of the importance of local technologies and scientific institutions, therefore, more universities where established in addition to scientific and research institutions [42].

In 1917, one of the largest research institutions was established "Institute of Physical and Chemical Research" for academic and practical purposes in order 
to support industries. The decision of establishing the Institute of Physical and Chemical Research was taken after discussions between businesses, the government, and the academics, and by 1945 it produced around 800 patents in Japan and 200 overseas, where some of them were been utilized by Japanese companies. In 1933 the science council was established in order to increase research funds and promote efficient research management. On ward companies started to have their own R\&D laboratories, and in 1923, there were 162 private R\&D laboratories under companies, some of these companies are well known these days such as; Toshiba (Emergence of Hibaura Seisakusho and Tokyo Denki) and Mitsubishi Heavy Industries (Mitsubishi Shipbuilding by that time) [42].

With the twitch of the Chinese-Japanese war (1937$1945)$ the heavy industry production boosted in addition to R\&D activities. During 1930 there were around 349 research organizations, which more than doubled in 1942 to total of 1154 research organization; 711 private organizations and 443 public research organizations together recorder a total $\mathrm{R} \& \mathrm{D}$ expenditures of 886 million yen. Due to the mentioned boost in $R \& D$ activities Japan started to have the ability of building world class level products such as aircrafts, ships, alloys, etc, however, they also were dependent on foreign technologies (American, and Europe) on many aspects which was one of the main reasons behind Japan losing in the second WW due to the stoppage of technology transfer [42].

\subsubsection{Japan during 1945 to the early 1970's}

Japan's economy faced a huge disaster after the second WW; especially the heavy industry production which decreased dramatically comparing to the peak level in 1934-1936, elaborating more, the R\&D activities and resources which were built and kept on increasing in the prewar period were destroyed. At that point Japan government realized how delayed they are in technology comparing to other countries, therefore, the rebuilding era is being repeated [42].

The most advantage by that time Japan had was that their military expenditures almost went to zero and all resources were directed to civilian production. Japan regained its prewar economic level in five years especially during the Korean War booming. Also, some studies referred Japans high rate of economic growth at that period to the high accumulation of capital with the technological progress. For the process of catching up Japan decided to promote both; technology importing and domestic technology creation [42].

\subsection{Brazil National Innovation System}

\subsubsection{From Colonialization to the Twentieth Century}

Brazil has the $9^{\text {th }}$ largest GDP in the world, the $6^{\text {th }}$ largest population and the $5^{\text {th }}$ largest area. The country has abundant natural resources, productive agriculture sector and diversified industrial base ([46-48]). Brazil has transformed itself during the period of time. During the era between 1500 and 1900, Brazil mainly dependent on its agricultural and mining resources. It was under the colonial rule of Portugal, when it progressed in the development of new seeds, crop and mining technologies, military engineering etc [49].

The first three decades of twentieth century saw the beginning of industrialization in Brazil. This was mainly because of the depletion of the surface resources which called for better technologies and the World Wars where the imports stopped and Brazil was on its own. Most of the Brazil's technology was obtained by copying from abroad and through firm-to-firm diffusion [49].

The second Vargas (1951-1954) and the Kubitschek governments (1956-1960) led to a $262 \%$ increase in the industrial sector. They focused on heavy industries and infrastructure, as well as encouraged foreign investments by providing subsidies and special treatment. Brazil strongly believed that atomic power was the key to military power and hence economic development. But poor economic management of the ambitious projects in the Kubitschek era led to instability, eventually resulting in a military coup in 1964 and hence 21 years of military rule $[24,50]$.

The military governments (1964-1985) worked towards planning and development and also increased support towards science and technology. They focused on reestablishing macroeconomic stability with the help of two National Development Plans. The Plans focused on increasing national power and creating energy selfsufficiency, but on the base of external borrowing. Hence Brazil entered a period of "debt-led growth" and this created more macroeconomic imbalances[24].

\subsubsection{Science and Technology Policies}

Three important financial institutions relating to Science and Technology were created during the first three years of the military period - FUNTEC, FINAME and FINEP. The Secretaria de Tecnologia Industrial (STI) established in 1972 also contributed to the development. Overall, the military period led to establishment of planning systems for S\&T and institutional development. The military government strictly restricted international technology transfer and laid emphasis on local technology development.

But the golden era was short lived. The debts, inflation and the macroeconomic instability wiped out most of the gains achieved and left the economy teetering. The only positives remaining were the build-up of human resource and the institutional developments, which could contribute to the future [24].

\subsubsection{Human Capital Formation}

Brazil's education system is one of the main obstacles to the country's modernization and technological upgrading. Technical development in any country is dependent on educated workforce. In $1980,73 \%$ of the 
labors had no education or hardly completed primary school. Low numbers and quality of full-time faculty, poor quality of postgraduate programs and low proportion of students doing science, mathematics and engineering were some other factors which undermined the whole education system. But Brazil's heavy investment on vocational and technical training provided some relief but not enough [24].

\subsubsection{Brazil's Competitive Position and the Technological Efforts of Brazilian Firms}

Since 1980, the Brazilian economy has declined in major industrial segments. The main reasons were oil shock, dept dependency, macroeconomic instability etc. The only exceptions were aircraft, telecommunications and electric distribution equipment. Very few firms in Brazil undertook R\&D. Most of them sought after exploitation of natural resources and reliance on low wage labor rather than on quality and productivity of labor and innovation in new and better products. Very few firms were regarded ad "R\&D active". Many of the R\&D producers were multinational firms with the aim of fulfilling local demands. Hence the international exports were not done and no benefits to the economy [24].

\subsubsection{Technology Policies}

Brazil had strict policies to minimize exchange outflow and control technology transfer. Moreover foreign firms were resilient in using locally their most advanced or upto-date technology mainly because of Brazil's weak trade secret protection bill which did not offer significant patent protection and weak trade secret protection. Brazil relied much less on the import of capital goods for acquiring foreign technology. This had negative impacts on the economy as this hampered competitiveness, modernization and excessive dependence on expensive and outmoded local goods. This also made foreign investment very less attractive [24].

\subsubsection{Financial incentives for local technology development}

Since 1973, FINEP (Agency for Financing Studies and Projects) has provided subsidized loans, risk-sharing instruments to accelerate national firm's technological activities. Government focused on mainly displacing international firms from certain key industrial segments. In short, the technology policy regime focused on short term objectives instead of producing internationally competitive technology [24].

\subsubsection{Public R\&D Institutes}

Development in various areas of engineering and mining technology was undertaken by few state level institutions. Public enterprises in-house R\&D covered sectors like energy, oil, telecommunications, aircrafts etc. Government R\&D failed mainly because of weak linkages with the productive sector or lack of focus. Only two sectors where government R\&D efforts had been effective were agro technology and aerospace. Examples of success in these fields are companies like Embraer and EMBRAPA [24, 51].

\subsection{Taiwan National Innovation System}

Taiwan's economic growth has been phenomenal and this has benefitted all income groups in the country. Some of the factors which contributed to the growth are high rate of savings, emphasis on education, land reform, favorable economic environment etc. [24].Taiwan's growth has mainly been contributed by the SMEs [52]. Taiwan knew that technology could never alone contribute to production and hence it also focused on improving the quality of its labor force.

\subsubsection{The Initial Base}

Many unconfirmed reports credit Japan to lay solid initial economic foundation in Taiwan before their withdrawal in 1945. Japanese came to Taiwan to import raw materials and agricultural products. During their colonial rule, they set up infrastructure with transportation, health care facilities etc. They also spread primary education in Taiwan. Taiwan's economy received another boost when 2 million educated and specialist Chinese migrated in 1949 [24].

\subsubsection{The economic environment and the characteristics of the firms in Taiwan}

In the early 1960s, the government realized that import substitution policies could not alone support economic growth and hence they set up export-promotion policies to revitalize its economies. This transformed the economy. Taiwan focused on developing labor intensive industries as they could be operated on smaller scale and with less capital. This led to the rise of SMEs which became the backbone of the economy [24].

\subsubsection{Sources of technology and the role of FDI enterprises}

SMEs adopted the role of OEM (original equipment manufacturing) supplier. This was beneficial as they made considerable profits and avoided the risk in developing the technology. This cooperation was topped by Japanese firms and Japan became the largest FDI (foreign direct investment) country investing in Taiwan in 1980s. Europe and US also played a part. They diffused their technologies to the domestic firms directly or indirectly (mainly through labor mobility). Another major source of foreign technology was reverse engineering technologies adopted by small firms. Summarizing the three major domestic sources of technology; firm's own R\&D through reverse engineering, purchasing domestic patents, and joint research with local research institutes [24].

\subsubsection{The Role of Government}


In 1959, a "Plan of National Long-Term Development of Science" was adopted as the basic guideline of development regarding science and technology. To carry out the plan, the Council on National Long-Term Development of Science was founded. Its main function was to design and carry out long-term research in sciences. In 1967, the council was reorganized as the National Science Council, and still is the main government organization for strategy and promotion of scientific research. There were many similar governmental organizations focusing to improve the quality of life, create capital intensive and technology intensive economic structure etc. [24].

\subsubsection{Educational Policy}

The growth rate in education in Taiwan was $4.87 \%$ for 30 years from 1950 to 1979 . This was a result of both the government policy and a strong desire for education. The total cost per student increased substantially in real terms for all levels of education, indicating improvement in educational quality. The reasons for demand in education were good financial returns, gains in social status, social and cultural factors etc. But along with it came the "brain-drain" problem. This was mainly encountered in the field of engineering. The government adopted many policies to counteract these problems [24].

\subsubsection{Fiscal and Financial Policy to promote technology development}

Therefore the government has taken a lot of measures to promote $R \& D$ in the private sector.

- R\&D expenses of firms deducted from the taxable income of that year as stipulated by Statute for Encouragement of Investment (SEI).

- Government introduced Assistance program for Strategic Industries (APSI) in 1982. To implement this, it put aside NT\$ 20 billion, in the form of loans which is given to firms.

- Lower interest rates and many other financial and non-financial programs

To encourage SMEs towards R\&D, two governmentsponsored research institutions were setup: Industrial Technology Research Institute (ITRI) and Institute for the Information Industry (III). Their main tasks included developing technology for industries and government, training and development and educating information professionals. They also setup technological alliances with major foreign companies like IBM etc. These alliances helped them benefit a lot from foreign technologies [24].

\subsubsection{Globalization of World's Economy}

To cope up with the trend of globalization, firms in Taiwan adopted a strategy of overseas merger. The government also was very supportive by providing low interest loans or part of investment capital etc. Overseas merger helped SMEs with a marketing channel, provided sophisticated technologies, created a brand name etc. [24].

\subsubsection{National Defense and Technology Development}

Taiwan's development of military weapons has been largely determined by its relationship with the United States. US supported the island's military-hardware needs till January 1979, before the US and the PRCs diplomatic relations broke off. Currently ITRI and Chung-Shan Science College are two major R\&D facilities for Air Force and the Navy [24].

\subsubsection{Indicators of development in Science and Technology}

It is very difficult for any country to come up with a set of indicators measuring progress made in Science and development. But the available data in Taiwan suggests that a lot of progress has been made in Science and Technology [24].

- The number of researchers in Science and Technology increased to 27,747 in 1986 from 8345 in 1979.

- In 1986, a total of 7395 papers were published in professional or academic journals, $74 \%$ of them in Taiwan and the remainder in foreign countries.

- In 1986, 13,355 patents were approved out of which $53 \%$ were that of Chinese nationals.

- Nature of exports is also an indicator. In 1950s, the main items of export were sugar, rice and bananas. Currently technology-intensive products like machinery constitute major share of exports.

\subsubsection{A National Plan}

The government is well aware that Taiwan has to accelerate its efforts in the development of science and technology in order to upgrade its economic structure, improve quality of life and strengthen national defense [24].

\section{Mapping United Arab Emirates (UAE) National Innovation System}

\subsection{UAE political over view}

The UAE area was occupied by the British, and in 1892 an agreement was signed at which UAE rulers started to deal in all economic and foreign relations along with the British, which remained in place till 1971 when the British military was withdrawn [53].

Al Nuhayyan family paved their control over Abu Dhabi in 1971 under the rule of Sheikh Zayid Bin Sultan (1966-2005). Sheikh Zayid Bin Sultan ruled AD after his brother Sheikh Shakhbut waver of the rule to him since Sheikh Zayid Bin Sultan proved himself as a great 
visionary and became the best candidate to rule Abu Dhabi under such economic boom. ([54]; [53]). Sheikh Zayid Bin Sultan ruled AD for 39 years and he was the person behind the unification and the creation of the federal supreme council which he sat as its first president [53], and Currently Sheikh Khalifa Bin Zayid Al Nuhayyan the son of Sheikh Zayid Bin Sultan rules AD ([53]; [55]).

The central authority of the UAE is based in Abu Dhabi, yet each of the UAE emirates is ruled by its original ruling family who ruled their emirate before the unification took place ([56],[54]). The Federal Supreme Council is the highest authority in the UAE and it directly oversees the national affairs of the state, in addition to foreign relations, defense, security, immigration, communications, health, labor affairs, and education. On the other hand, local governments do have jurisdiction over the remaining government services to certain extents, yet they are expected to play greater roles in some instances e.g. when the decentralized school management system was proposed [57]. The members of the Federal Supreme Council are the rulers of the seven emirates. The ruler of Abu Dhabi is the president, and the ruler of Dubai is the vice president.
The Federal National Council, a 40-member advisory body to the Federal Supreme Council, reviews proposed laws by the Council of Ministers or cabinet members who head up the various government functions and then recommends amendments to the laws, passage, or rejection. Ultimate authority regarding laws, however, rests with the Federal Supreme Council [56]. Members of the Federal National Council have been appointed by the rulers of the emirate states since its inception; seats are allocated based on population. The first limited public election (50 percent of the seats) of the Federal National Council took place in December 2006 [58].

\subsection{UAE Economic Over view}

Before the oil boom, the UAE depended on pearl business in supporting its economy, in addition to some agriculture, fishing, and artisans who hammered coffee pots or stitched sandals to wealthy pearl merchants and powerful Shaykhs, yet the pearl business was affected by the Japanese in mid-1900 through their cultured pearl cultivation, and as a result many workers tended to leave to Kuwait and Saudi Arabia to work in their oil fields.

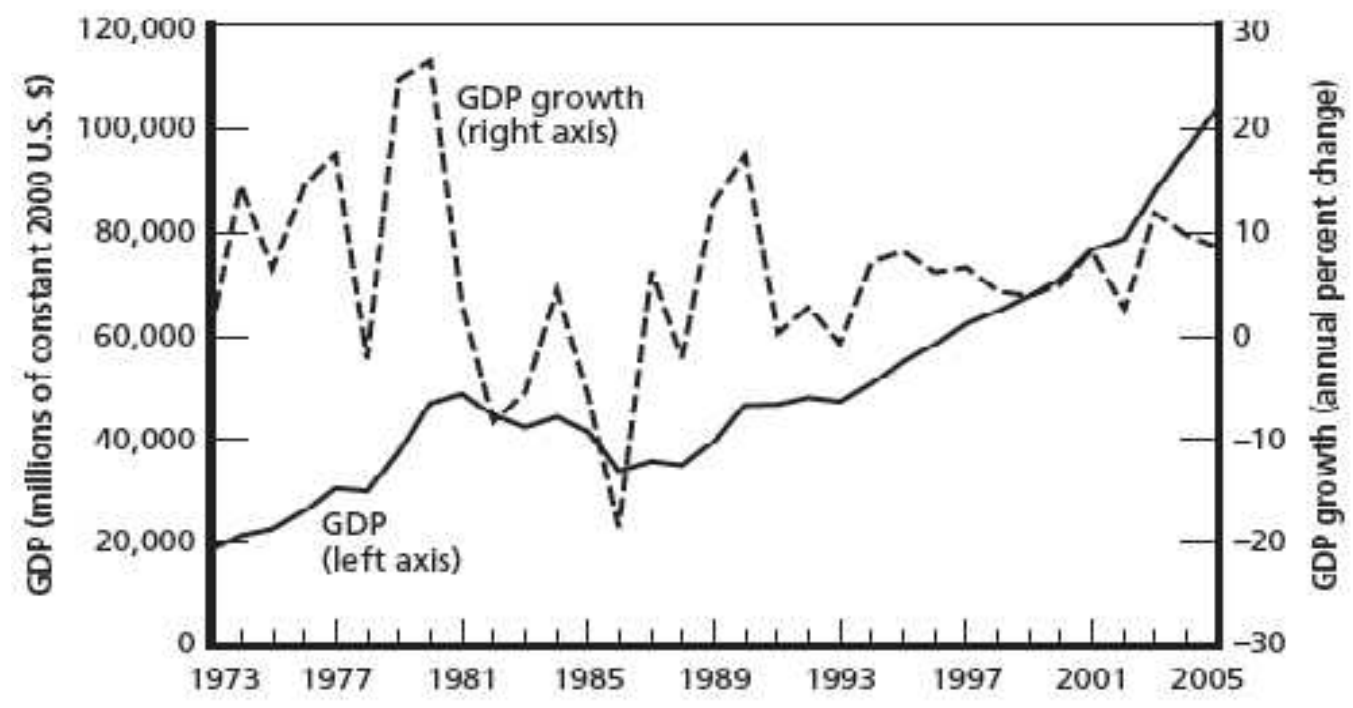

Figure 1, UAE GDP trends and growth between 1973 to 2005 [3]

Figure 1 reveals the substantial economic growth of the UAE over a short period of thirty years since the country's unification in 1971, and the literature refers to oil as a main reason behind it. Oil reserves in the UAE are distributed as follow, 94 percent of the total oil is located in Abu Dhabi, 4 percent in Dubai, 1.5 percent in Sharjah, and 0.1 percent in Ras' al Khayma which is being shared with the rest of emirates. In addition, gas reserves are also distributed and located with the same four cities [3]. The largest economic development can be seen in the four major oil and gas owner emirates, yet Abu Dhabi supports the other non-oil or gas producer cities in the UAE in order to offset their lack of resources and support their infrastructure development [53].
Adding, the literature argues that the service sector especially in Dubai played a significant role in the GDP where 55.1 percent of the GDP was added from industry [53]. At the current and due to the UAE oil wealth and efforts towards more diversified economy, the UAE has become a major player and influential element in the global economy, where it takes part of the World Trade Organization (WTO), OPEC, UN, GCC, and the Arab League [3].

\subsection{UAE Social and Education over view}

Due to the economic boom in the UAE, it faced a dramatic increase in its population due to immigrants who flow to 
UAE to cover job vacancies which UAE nationals failed to fill due to both lack of skilled workers and number [3]. Population growth was mainly due to expatriates with a considerably small growth in UAE nationals as shown in the following table.

Table 1 reveals that in the period between 1975 and 2004 expatriates in the UAE increased by almost 858 per from 356,000 to $3,414,000$ accounting for more than 80 per of total UAE population in 2004.

Formal education in the UAE started to form in the period between 1907-1953, and in order to monitor the school system expansion "Dai'rat Al Maarif" was established in 1936 and the modern school system was formed in 1953-1954. After the UAE unification "Dai'rat Al Maarif" was changed to the ministry of education which started opening governmental schools across the UAE [57]. With the creation of more schools many teachers started flowing to the UAE to cover the need of teachers since a small number of UAE nationals were trained for such positions [56].

In 1977 UAE University was established as the first post-secondary school offering various fields and majors with the exception of engineering studies. In 1988 the Higher College of Technology (HCT) was established in order to start offering engineering studies that UAE University did not offer, and in 1998 Zayed University was established which offers various majors $[59,60]$.

The literature depicts that post-secondary enrolment rate as well as graduation rate is higher for UAE national females in comparison to males [3], where females represented around 78 percent of the UAE University enrolled students in 2005-2005 [3]. As crucial, females in the UAE count for lower employment rate due to social and culture factors [3].

The UAE education was criticized through literature, where employers highlighted the bad graduate qualities from different aspects mainly technical ([58], p. 14). Elaborating more, a crucial deficiency in the UAE education system is its isolation from the market and industries, also as a result of such deficiencies the Emirates employment rate in the private sector becomes less [61].

Abdelkarim and Haan [62] highlighted the importance of fund allocation toward technical and soft skill training courses, where they highlighted the low role done by the public sector towards such trainings, they criticized the un-training-led culture of the UAE where most of the training are related to new technologies not to create economic development.

\section{Abu Dhabi 2030 Vision}

In 2006, his highness Sheikh Mohammed Bin Zaid mandated the General Secretarial of the Executive Council, the Abu Dhabi Council for Economic development and the Department of planning and Economy to start developing the 2030 vision for Abu Dhabi; therefore, achieving the vision of his Highness Sheikh Khalifah Bin Zaid. Since then, 2030 is considered an important milestone for Abu Dhabi at which its economy will reach a tangible and remarkable diversification and sustainability [63]

The vision came to sustain and keep the successful city with the ultimate aim of creating a safe and secured society and a dynamic open economy. In 2007/2008 the Abu Dhabi policy agenda defined the main pillars of its vision in order to achieve its goals, and based on the mentioned pillars four key priority areas were defined [63].

Pillars of the Abu Dhabi policy agenda vision:

1- A large empowered private sector

2- The creation of a sustainable knowledge based economy

3- An optional transparent regulatory environment

4- A continuation of strong and diverse international relationships

5- Emirate resource optimization

6- Premium education, healthcare and infrastructure

7- Complete international and domestic security

8- Maintaining Abu Dhabi's values, culture, and heritage

9- A significant and ongoing contribution to the federation of the UAE

Priority areas:

1- Economic development

2- Social and human resources development

3- Infrastructure development and environment sustainability

4- Government operations optimization

The four key areas are vitally significant and understanding them is crucial for the vision's success. The first key area "Economic Development" was described in the vision as the potential area to reach a diversified economy which should help creating higher value employment opportunities, increase the role of women in economy, and minimize the GDP volatility. Therefore, the government of Abu Dhabi is planning to stimulate investments and encourage entrepreneurial activities through rigorous legislative reforming based on strong analyses that are based on qualitative data. The second key area was "Social and Human Development", this area is as clear as a person can read it, since having a better education and health can lead to higher quality employees. In addition, having higher quality employees can fuel and support the first key area "Economical Development" as well. Next was "Infrastructure Development and Environment Sustainability", a number of key actions to be done by Abu Dhabi government were mentioned; Building professional and fully managed urban environment cities, with the best traffic systems. Next was taking the responsibility of maintaining the city's security making it a better place to live and work. Final area of focus was "Governmental 
operations optimization", increasing the efficiency of the governmental departments and clarifying the governmental role in the 2030 vision is what this last point highlights. A great initiative can be noticed toward this last key area where some of the governmental processes can already be done through well designed epages, and that can highlight the understanding of the ICT (Information and Communication Technology) power by the government of Abu Dhabi. Abu Dhabi has targeted through its vision that $64 \%$ of the total GDP will be from non-oil sectors and the oil effect on GDP will just present $36 \%$. Therefore a number of sectors where defined to help in pushing the economical growth and help in reaching the required diversification. The defined sectors were: (i) Energy-Oil and Gas (ii) Petrochemicals (iii) Metals (IV) Aviation, Aerospace and Defense (V) Pharmaceutical, Biotechnology, \& Life Science (VI) Tourism (VII) Healthcare Equipment \& Services (VIII) Transportation, Trade, \& Logistics (IX) Education (X) Media (XI) Financial Services, and (XII) Telecommunication Services. Finally and worth highlighting, the 2030 vision mentioned that the aviation and aerospace market is worth nearly $\$ 500$ billion. The aviation and aerospace sector is what this research paper will be studying. Afterward, the potential success or failure of such a sector in Abu Dhabi will be evaluated $[63,64]$.

\section{Conclusion and Further Work:}

Looking into the five selected countries NIS, the one can notice key elements playing crucial roles either in supporting innovation or otherwise damping its existence, which automatically affects the overall country's economic performance. Keeping in mind the main element of NIS which the literature focused on "Networks and interactions" most of what happened across the five countries went around it and lobbied to assure its existence. On the other hand, the other two basic building blocks of the NIS can be noticed as well which also played a role in the countries NIS to some extent.

In the case of the US, knowledge and technology networks played a crucial role in the early stages of its development, in addition to their ability in creating science industry relation that minimized secrecy across the national level through various techniques such as horizontally developed industries and their decentralized universities system, where on the contrast was France which suffered from the science-industry divorce which affected their science great era negatively affecting automatically their vertically arranged industry. Looking into Japan, their power in importing foreign technologies through the above mentioned means, with their focus on building skilled human capital that can further advance such technologies supported their industry and took them to their current success in addition to other mentioned factors such as entrepreneurship activities which is one of the SI functions mentioned previously that is believed as one of the main factors behind Japan's success.
Looking into the gathered UAE literature, an immature innovation system can be depicted, where the UAE lacks a number of crucial pillars of innovation such as flows and networks between science and industry, in addition the education system quality and post graduates were criticized and the lack of technical people and engineers was obvious, where the five countries worked on strengthening and increasing their engineers numbers and quality, and the UAE immature NIS can also be seen through the relatively small number of scientific and technical journal articles which can illustrate the lower research activities in the region as shown inn Figure 2. Adding, the UAE nationals are the smaller portion of the UAE and with un-secured residency of expatriates, the UAE national are the ones who are mostly supposed to play the entrepreneurs role, which Joseph Schumpeter highlighted as crucial for economic development. As last, for the five mentioned countries it can be seen that intensive $R \& D$ and $T \& S$ investments played a huge role in their advancement. In the case of UAE the R\&D data was scarce yet a report highlighted that in 2030 the expected R\&D expenditures will be around $0.75 \%$ of GDP, and that is still lower than US, France, Japan, and Brazil in 2008 as shown in Figure 3 [65], and that can also give an indication of low current $R \& D$ expenditures. On the other hand UAE do not have financial problems with their high GDP per capita, which can prevent them from falling into similar trap which Brazil fall into of having a debt-driven development.

Based on the above mentioned, a number of abstract policy aimed recommendations can be proposed, which can support the overall innovation system in the UAE:

1- $\quad$ Since UAE is entering various industries as what has been previously highlighted, creating links and flows across them at which both tacit and explicit knowledge can be shared can be seen as very crucial for their NIS.

2- Creating decentralized university system and stimulating private and government $R \& D$ organizations with private policies to certain extent forcing them to lobby for resources.

3- Provide UAE nationals with incentives to create their own companies.

4- Provide longer term residency security to expatriates, experienced people in specific.

5- Deliver market needs and support market formations to citizens to stimulate the creation of new firms and diversification in existed ones.

Since much of the preceding discussion was based on secondary data, more insights would be possible to reveal through conducting an empirical investigation. It is, therefore, suggested that a set of in-depth interviews should be conducted with various actors within the UAE's NIS in order to both identify the current challenges and inform policymaking. 


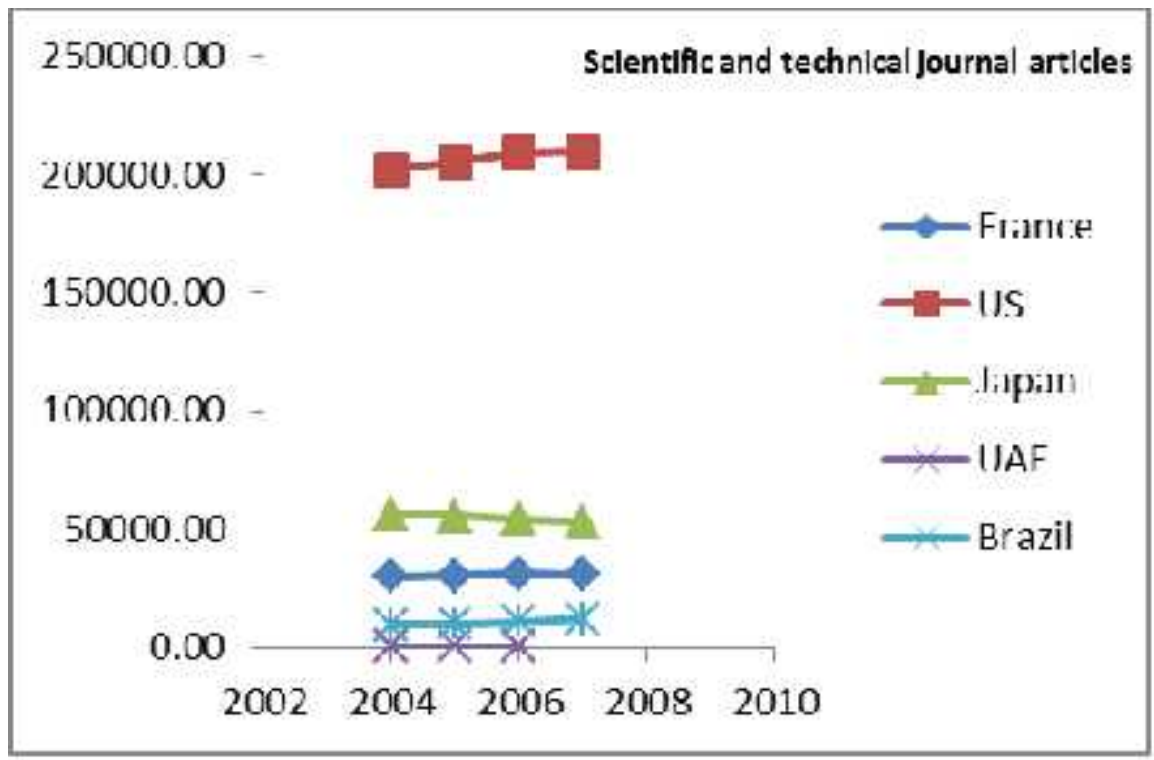

Figure 2 Number of scientific and technical journal articles [2]

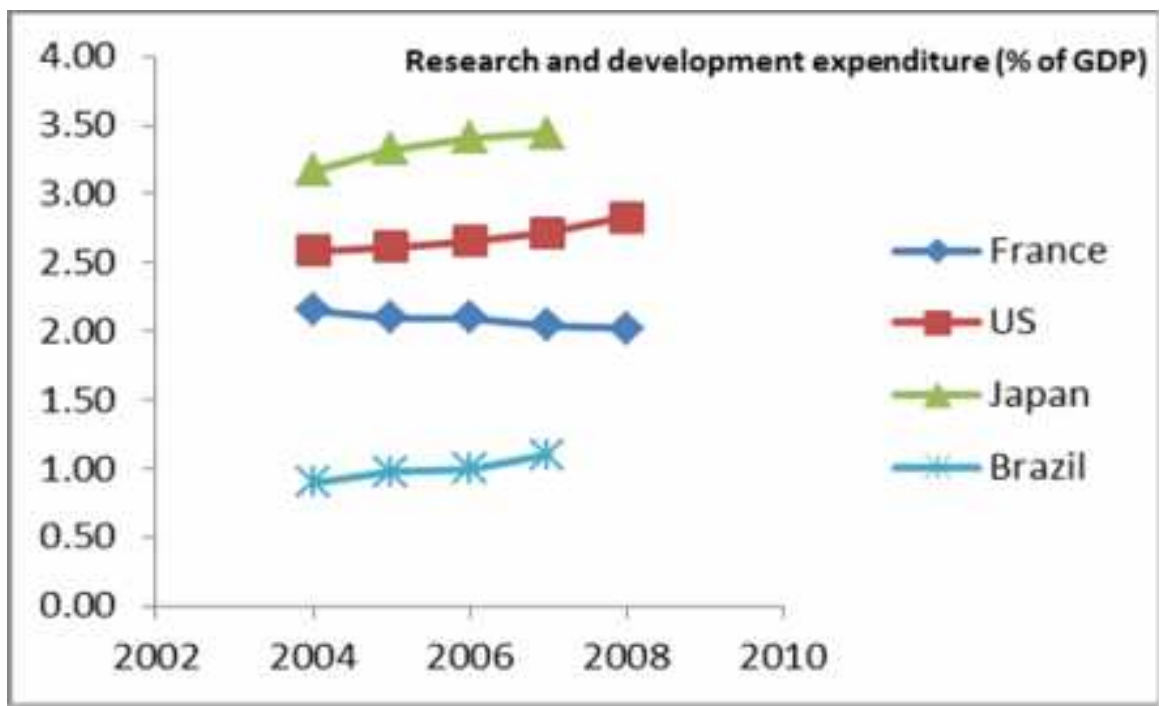

Figure 3 R\&D expenditures (\% of GDP) [2]

\section{Acknowledgments}

The authors would like to thank Dr. Yasser Al Saleh for his time spent reviewing the paper and his excellent feedback.

\section{References}

[1] Morris, M.J., Organisation, social change and the United Arab Emirates. 2005.

[2] The World Bank [cited 2012 29-Jan]; Available from: http://www.worldbank.org/.

[3] Gonzalez, G., Facing human capital challenges of the 21st century: education and labor market initiatives in Lebanon, Oman, Qatar, and the United Arab Emirates2008: Rand Corp.
[4] Economic Development. Available from: http://gsec.abudhabi.ae/Sites/GSEC/Navigation/EN/Policy AndStrategy/economic development,did=89918.html \#id89922.

[5] Hight, G.N., Diversification Effect: Isolating the Effect of Correlation on Portfolio Risk.

[6] Nelson, R.R., Building effective'innovation systems' versus dealing with'market failure'as ways of thinking about technology policy. The New Economics of Technology Policy, 2009: p. 7.

[7] Edquist, C., Innovation policy-a systemic approach. The Globalizing Learning Economy. Oxford University Press, Oxford, 2001: p. 219-239.

[8] Spielman, D.J., Innovation systems perspectives on developing-country agriculture: A critical review. ISNAR (International Service for National Agricultural Research) Discussion paper, 2006. 2. 
[9] McCraw, T.K., Prophet of innovation: Joseph Schumpeter and creative destruction2007: Belknap Press.

[10] Edquist, C., Systems of innovation. The Oxford handbook of innovation, 2005: p. 181-208.

[11] Kraemer-Mbula, E. and W. Wamae, Innovation and the development Agenda2010: Publications de l'OCDE.

[12] Mason, O.T., The origins of invention: a study of industry among primitive peoples. Vol. 28. 1896: W. Scott.

[13] Archibugi, D., J. Howells, and J. Michie, Innovation systems in a global economy. Technology Analysis and Strategic Management, 1999. 11(4): p. 527-539.

[14] Lundvall, B.Å., National systems of innovation: Toward a theory of innovation and interactive learning2010: Anthem Pr.

[15] Carlsson, B. and R. Stankiewicz, On the nature, function and composition of technological systems. Journal of evolutionary economics, 1991. 1(2): p. 93-118.

[16] Gao, S. and H. van Lente, Comparing approaches to systems of innovation: Confronting to the Chinese telecommunication sector.

[17] Edquist, C. The Systems of Innovation Approach and Innovation Policy: An account of the state of the art. 2001.

[18] Bergek, A., et al., Analyzing the functional dynamics of technological innovation systems: A scheme of analysis. Research Policy, 2008. 37(3): p. 407-429.

[19] OECD, National Innovation Systems, 1997, Patel P., Pavitt, K.: Paris.

[20] Bozeman, B., M. Gaughan, and B. Sampat, Knowledge Flows and Knowledge Collectives: Understanding The Role of Science and Technology Policies in Development2003: Rockefeller Foundation.

[21] Niosi, J., National systems of innovations are. Research policy, 2002. 31(2): p. 291-302.

[22] Ronald, D., Technology policy and economic performance; lessons from Japan : Christopher Freeman, (Frances Printer Publishers, London, New York, 1987) pp. 155, £20.00. Research policy, 1988. 17(5): p. 309-310.

[23] Lundvall, B.- $\AA$., National Systems of Innovation: Towards a Theory of Innovation and Interactive Learning1992, London: Pinter Publishers.

[24] Nelson, R.R. and N. Rosenberg, Technical innovation and national systems. National innovation systems: A comparative analysis, 1993: p. 3-21.

[25] Edquist, C. and B.A. Lundvall, Comparing the Danish and Swedish systems of innovation. National innovation systems, 1993: p. 265-298.

[26] Patel, P. and K. Pavitt, The nature and economic importance of national innovation systems. STI ReviewOECD Paris, 1994. 3(14): p. 9-32.

[27] Metcalfe, S., The economic foundations of technology policy: equilibrium and evolutionary perspectives. Handbook of the economics of innovation and technological change, 1995. 446.

[28] Niosi, J., et al., National systems of innovation: in search of a workable concept. Technology in society, 1993. 15(2): p. 207-227.
[29] C.MOWERY, D. and N. ROSENBERG, National innovation systems: a comparative analysis 1993: Oxford University Press, USA.

[30] Chandler, A.D., The visible hand: The managerial revolution in American business1977: Belknap Pr.

[31] Stigler, G.J., Monopoly and oligopoly by merger. The American Economic Review, 1950. 40(2): p. 23-34

[32] Mowery, D.C., The Boundaries of the US Firm in R\&D, 1995, University Of Chicago Press.

[33] Mowery, D.C., Industrial research and firm size, survival, and growth in American manufacturing, 1921-1946: an assessment. Journal of Economic History, 1983. 43(4): p. 953-980.

[34] Terleckyj, N.E. Measuring economic effects of federal research and development expenditures, recent history with special emphasis on federal R\&D performed in industry (Paper prepared for the Workshop on the Federal Role in Research and Development, National Academies of Science and Engineering, Washington DC). 1985. National Academies Press.

[35] Danhof, C.H., Government Contracting and Technological Change 1980: Greenwood Press (CT).

[36] Flamm, K., Creating the computer: government, industry, and high technology1988: Brookings Institution Press.

[37] Perry, W.J., Cultivating technological innovation. The Positive Sum Strategy: Harnessing Technology for Economic Growth, eds. R. Landau and N. Rosenberg (Washington, 1986: p. 443-51.

[38] Gillispie, C.C., Science and polity in France: the end of the old regime2004: Princeton Univ Pr.

[39] Chesnais, F., National innovation systems: a comparative analysis 1993: Oxford University Press, USA.

[40] Shinn, T., Failure or Success? Interpretations of 20th Century French Physics, 1986, JSTOR. p. 353-369.

[41] Gilpin, R. and C.o.i. studies, France in the Age of the Scientific State1968: Princeton University Press Princeton, NJ.

[42] Hiroyuki in Nelson, R.R., National innovation systems: A comparative analysis. 1993.

[43] Suzuki, K., S.H. Kim, and Z.T. Bae, Entrepreneurship in Japan and Silicon Valley: a comparative study. Technovation, 2002. 22(10): p. 595-606.

[44] Itō, T., The Japanese Economy. Vol. 10. 1992: The MIT Press.

[45] Freeman, C., The 'National System of Innovation' in historical perspective. Cambridge Journal of economics, 1995. 19(1): p. 5-24

[46] Ramos, L.R., et al., Two-year follow-up study of elderly residents in S. Paulo, Brazil: methodology and preliminary results. Revista de Saúde Pública, 1998. 32(5): p. 397-407.

[47] Garrafa, V., Bioethical Radiograph of Brazil. Acta Bioethica, 2000. 1: p. 177-181.

[48] Nass, L.L., P.A.A. Pereira, and D. Ellis, Biofuels in Brazil: an overview. 2007. 
[49] j., C. and C. R., Technical innovation and national systems. National innovation systems: A comparative analysis1993: Nelson, R.R. 3-21.

[50] Vavrus, J., Institutions and the Evolution of Development Economic Thought in Brazil: 1950-1980.

[51] Vertesy, D. and A. Szirmai, Brazilian aerospace manufacturing in comparative perspective: A Brazil/USA comparison of output and productivity2010: UNUMERIT, Maastricht Economic and Social Research and Training Centre on Innovation and Technology.

[52] Hu, M.W. and C. Schive, The changing competitiveness of Taiwan's manufacturing SMEs. Small Business Economics, 1998. 11(4): p. 315-326.

[53] UAE Yearbook 2006, 2006, United Arab Emirates Ministry of Information and Culture: Abu Dhabi: Ministry of Information and Culture.

[54] Zahlan, R.S., The Making of the Modern Gulf States: Kuwait, Bahrain, Qatar, the United Arab Emirates, and Oman1998: Ithaca.

[55] Al Baik, D. and S. Al Nowais, Ministers Welcome Smooth Transfer of Power. gulfnews. com, January, 2006. 6.

[56] Metz, H.C. and L.o.C.F.R. Division. Persian Gulf States: Country Studies. 1994. Federal Research Division, Library of Congress.
[57] History of Education in the United Arab Emirates. 2010; Available http://www.moe.gov.ae/English/Pages/UaeEduH.aspx.

[58] Ahmad, A.H., Stage Set for Country's First FNC Elections. gulfnews. com, September, 2006. 14.

[59] Higher College of Technology (HCT). Available from: http://www.hct.ac.ae.

[60] Zayed University. [cited 2012 1-31]; Available from: http://www.zu.ac.ae/studentrecruitment/admissions.htm.

[61] Al-Fakhri, J.J., The Demographic Structure of the GCC States. The Gulf in a Year-2003: p. 68-80.

[62] Abdelkarim, A. and H.C. Haan, Skills and Training in the UAE: The Need for and the Dimensions of Institutional Intervention2002: Tanmia, Centre for Labour Market Research \& Information.

[63] Executive Council General Secretariat, D.o.P.E., and Abu Dhabi Council for Economic Development (ADCED), The Abu Dhabi Economic Vision 2030, 2008.

[64] COUNCIL, T.E., Policy Agenda 2007-2008 The Emirate of Abu Dhabi.

[65] Ajami, I. Abu Dhabi eyes tech future. 2010; Available from: http://gulfnews.com/business/opinion/abu-dhabieyes-tech-future-1.656897 